\title{
Inflammation and Adaptive Immunity in Parkinson's Disease
}

\author{
R. Lee Mosley, Jessica A. Hutter-Saunders, David K. Stone, and Howard E. Gendelman \\ Movement Disorders Program, Department of Pharmacology and Experimental Neuroscience, Center for \\ Neurodegenerative Disorders, University of Nebraska Medical Center, Omaha, Nebraska 68198 \\ Correspondence: hegendel@unmc.edu
}

\begin{abstract}
The immune system is designed to protect the host from infection and injury. However, when an adaptive immune response continues unchecked in the brain, the proinflammatory innate microglial response leads to the accumulation of neurotoxins and eventual neurodegeneration. What drives such responses are misfolded and nitrated proteins. Indeed, the antigen in Parkinson's disease (PD) is an aberrant self-protein, although the adaptive immune responses are remarkably similar in a range of diseases. Ingress of lymphocytes and chronic activation of glial cells directly affect neurodegeneration. With this understanding, new therapies aimed at modulating the immune system's response during PD could lead to decreased neuronal loss and improved clinical outcomes for disease.
\end{abstract}

$P^{n}$ rkinson's disease (PD) is the second most common neurodegenerative disorder affecting the elderly. Pathologically, the disease is characterized by the cytoplasmic accumulation of proteinaceous aggregates called Lewy bodies (LBs), which are mainly comprised of $\alpha$-synuclein ( $\alpha$-syn) and ubiquitin (Spillantini et al. $1997,1998)$. Progressive degeneration of dopaminergic neurons in the substantia nigra (SN) pars compacta and their projections into the caudate nucleus leads to substantial decreases in dopamine levels, which manifest as resting tremor, bradykinesia, rigidity, and gait dysfunction (Dauer and Przedborski 2003). Currently, no curative treatments or treatments that interdict disease progression exist. Although the etiology of PD remains unknown, abundant evidence implicates immune system abnormalities and central nervous system (CNS) inflam- mation in disease pathobiology (McGeer et al. 1988a; Stone et al. 2009; Kosloski et al. 2010). Harnessing inflammatory responses through targeted modulation of innate and adaptive immune responses has gained increasing interest in recent years as a potential therapeutic strategy. The interplay between innate and adaptive immunity in the pathobiology of PD, the evolution and change in such immune responses, and the means to alter it to the benefit of the diseased, is the focus of this article.

\section{ADAPTIVE IMMUNITY AND THE CNS}

William Hickey wrote, "vertebrates possess two bodily systems capable of learning and remembering: the nervous system and the immune system" (Hickey 2001; Weiner 2008). The CNS was once thought to be an "immune privileged"

Editor: Serge Przedborski

Additional Perspectives on Parkinson's Disease available at www.perspectivesinmedicine.org

Copyright (C) 2012 Cold Spring Harbor Laboratory Press; all rights reserved; doi: 10.1101/cshperspect.a009381

Cite this article as Cold Spring Harb Perspect Med 2012;2:a009381 
site, in which immune cells of the periphery could not enter or rarely entered, and thus the two systems had little to no interaction. This hypothesis was supported by the early observation that tissue grafts in the eye or brain survived longer than grafts in other areas of the body (Medawar 1948). However, today, evidence of an interactive adaptive immune system and the CNS abounds. Indeed, communication between the CNS and peripheral immune system is much more fluid than previously considered and, as such, may substantially affect disease progression in neurological disorders (Ferrari and Tarelli 2011). Peripheral immune responses can trigger inflammation and exacerbation of CNS degeneration in several neurodegenerative diseases such as Alzheimer's disease (AD), multiple sclerosis (MS), amyotrophic lateral sclerosis (ALS), stroke, and prion-mediated diseases (Cunningham et al. 2005a,b; Kamer et al. 2008; Fiala and Veerhuis 2009; Holmes et al. 2009; Lee et al. 2009a; McColl et al. 2009; Reale et al. 2009; Stoll and Bendszus 2009; Teeling and Perry 2009; Heesen et al. 2010; Perry 2010), and particularly PD (Hasegawa et al. 2000; Arai et al. 2006). In those disorders, increasing inflammation and breakdown of the blood-brain barrier (BBB) forces increased communication between the CNS and peripheral immune systems as evidenced in several neurodegenerative diseases with increased leukocyte migration within the brain parenchyma (Stolp and Dziegielewska 2009). Under infectious or inflammatory conditions, peripheral immune cells have relatively unfettered access to the CNS. These immune cells influence neuroinflammation and neurodegeneration not only in a paracrine fashion, but also in an endocrine fashion. In turn, the CNS is capable of influencing the immune response to pathogens in the periphery through the neuroendocrine system. Thus, the immune system is not only charged with protecting the CNS from pathogens and injury, but is also capable of affecting the functions and homeostasis of resident CNS cells, for better or worse. Furthermore, researchers are beginning to harness the neurotrophic effects of the immune system to aid in repair and regeneration in the CNS.
Even under normal conditions, activated $\mathrm{T}$ and B lymphocytes patrol the CNS in low numbers, whereas naïve lymphocytes are excluded (Hickey 1999; Togo et al. 2002; Engelhardt and Ransohoff 2005). Although fewer activated $\mathrm{T}$ cells infiltrate the normal CNS than other tissues (Yeager et al. 2000), this may be owing to the low level of adhesion molecules expressed on endothelial cells under normal conditions (Hickey 2001), whereas increased expression of adhesion molecules leads to increased lymphocyte infiltration. When cytokines such as interleukin (IL)-1 and tumor necrosis factor (TNF) $\alpha$ are secreted by activated glia in the brain, or are present in circulating blood, permeability of the BBB is increased and the expression of cellular adhesion molecules (such as selectins) on microvascular endothelial cells are up-regulated (Wong et al. 1999). Activated $\mathrm{T}$ cells and $\mathrm{B}$ cells are then able to extravasate and migrate to the site of neuronal injury in increased numbers (Aloisi et al. 1999; McGeer and McGeer 2003; Olson and Miller 2004).

Indeed, abnormalities in the BBB have been shown where T-cell infiltration occurs in neuroAIDS (Petito and Cash 1992; Petito et al. 2003), AD (Rogers et al. 1988; Togo et al. 2002; Desai et al. 2007), and PD (Farkas et al. 2000). Furthermore, whereas the CNS lacks a defined lymphatic system, antigens do exit the CNS via arachnoid villi, cranial nerves, and spinal nerve root ganglia to lymph (Cserr and Knopf 1992). Once in the lymph, these antigens may be taken up by dendritic cells, processed, and presented to T and B cells to mobilize an adaptive immune response to the CNS. Whereas acute neuroinflammation is beneficial to regaining homeostasis and normal function of the CNS after injury or infection, chronic neuroinflammation is damaging to the CNS and may initiate or amplify neurodegeneration associated with HIV-1 encephalitis, AD, or PD.

\section{Cross-Regulation of Adaptive and Innate Immunity in the CNS}

Innate immunity consists of the immune mechanisms that are encoded in the germline and are possessed at birth, and work in a "nonspecific" 
manner, for immediate defense against microbial infection, notably sepsis (Perry 2011; Stearns-Kurosawa et al. 2011). A host's first line of defense consists of physical barriers such as skin- and cell-regulated enzymes used to clear pathogens and debris, and serves to remove foreign substances by phagocytosis, to recruit immune cells to sites of infection, to activate the complement cascade, but most importantly, to process and present antigens for activation of and recognition by the adaptive immune response (Kim 2005; Filias et al. 2011; Sakaguchi 2011; Sly and Holt 2011; Veerhuis et al. 2011). Its conservation is matched only by its simplicity, except for a broad range of self-nonself pattern-recognition receptors. Such immune activation functions are through nonspecific, generic recognition of common cell signaling pathways shared through a host of endogenous and exogenous factors. These pathways are gaining considerable interest in therapeutic development (Goldman 2007; Basith et al. 2011). Cell debris and foreign matter within the CNS engage toll-like receptors (TLRs), which are expressed by microglia, astrocytes, oligodendrocytes, as well as by neurons (Lv et al. 2011; Zurolo et al. 2011). Engagement of TLRs activates signaling cascades that result in proinflammatory cytokine and chemokine production and in effects on the brain directly or indirectly through glial or BBB function (Franklin et al. 2011; Greenwood et al. 2011; Holman et al. 2011; Kacimi et al. 2011).

The innate immune system also is linked to its adaptive arm through the abilities to provide required "signals" for antigen presentation and to act as final effectors by T-cell-mediated responses in the CNS. The interrelationships between innate and adaptive immunity permit the host to recognize environmental and exogenous cues and work in concert to protect and sustain the host. Central to the innate immune network are microglia (Perry 2011). They secrete both anti- and proinflammatory cytokines and chemokines together with other factors that regulate not only adaptive immunity, but also neural function and neural homeostasis. Those microglial factors found in the brain, cerebrospinal fluid (CSF), and peripheral blood in- clude transforming growth factor beta (TGF$\beta)$, IL-1 alpha/beta (IL- $1 \alpha / \beta)$, IL-6, IL-10, IL-12, IL-23, and TNF- $\alpha$, many chemokines (RANTES/CCL5, MCP-1/CCL2, and IP-10/ CXCL10), proteolytic enzymes, matrix metalloproteinases, complement, growth factors, and glutamate (Griffin et al. 1989; Dickson et al. 1993; Moore and Thanos 1996; Qiu et al. 1997). Moreover, COX-2 is present as increased levels of TRAF family member-associated NFкB activator (TANK) and NFKB1 in the SN, and IL-15, RANTES, and IL-10 levels are significantly elevated in brains and peripheral circulation in PD patients (Blum-Degen et al. 1995; Teismann et al. 2003; Rentzos et al. 2007, 2009; Reynolds et al. 2008a). Furthermore, innate immunity regulates lymphocyte infiltration into the CNS. Cytokines, such as IL-1 $\beta$ and TNF- $\alpha$, secreted by activated glia or endothelial cells increase BBB permeability (Desai et al. 2007), and the expression of cellular adhesion molecules (such as E-selectin) on microvascular endothelial cells are up-regulated (Wong et al. 1999), together increase permeability of the BBB and increase homing, extravasation, and activation of lymphocytes.

Of the antiinflammatory cytokines produced by $\mathrm{T}$ cells, macrophages, and microglia, TGF- $\beta$ modulates injurious responses to the brain (Finch et al. 1993) and suppresses proinflammatory microglia and T-cell responses (Sakaguchi 2004), and as such may represent a neuroprotective host response (Chao et al. 1994). However, TGF- $\beta$ released from the damaged brain microvasculature contributes to inflammation by increasing expression of endothelial IL-1 $\beta$ and TNF- $\alpha$ (Grammas and Ovase 2001). The engagement of TLRs leads to translocation of nuclear factor- $\kappa$ light-chain enhancer of activated B cells $(\mathrm{NF}-\kappa \mathrm{B})$ and AP1 to the nucleus where they induce transcription of a broad range of innate immune proteins. Once activated, microglia secrete both neurotrophic and neurotoxic factors (Zhang and Fedoroff 1996; Glezer et al. 2007); proinflammatory cytokines including IL- $1 \alpha$, IL- $1 \beta$, and TNF- $\alpha$ (Giulian et al. 1986; Sawada et al. 1989); and neurotrophins including nerve growth factor (NGF) and neurotrophin 3 (NT-3) (Elkabes 
R.L. Mosley et al.

et al. 1996; Heese et al. 1998). However, during chronic inflammation, the neurotoxic effects of microglia are proposed to eventually outcompete the neurotrophic effects, thus increasing neurodegeneration (Rock et al. 2004). In turn, increased inflammation and BBB permeability allow naïve $\mathrm{T}$ cells greater entry and accessibility to activated microglia that in the acute phase induce proinflammatory T-cell responses, and can, under chronic conditions, perpetuate the inflammatory state by engaging and activating polarized proinflammatory effector $\mathrm{T}$ cells that have expanded in the periphery and ingressed to sites of neurodegeneration.

\section{Induction of Innate and Adaptive Immune Activation by Misfolded Proteins}

Evidence abounds for the involvement of misfolded proteins in the pathology of neurodegenerative diseases, as well as in the activation of microglia and antigen-presenting cells (APCs) that function to induce the adaptive immune arm. In PD, LBs are associated with activated microglia and dopaminergic neuronal death. LBs are comprised mostly of $\alpha$-syn, ubiquitin, and neurofilament (Goldman et al. 1983; Spillantini et al. 1997, 1998; Jellinger 2007) and posttranslationally modified forms of $\alpha$-syn have an increased propensity to aggregate (Uversky et al. 2005; Cavallarin et al. 2010). These $\alpha$-syn species are created by ubiquitination (Shimura et al. 2001), phosphorylation (Fujiwara et al. 2002), or oxidation and nitration (Giasson et al. 2000), and are found in LB inclusions, extraneuronally in PD brains (Lee 2008), and in the periphery of PD patients (Beach et al. 2010). Abnormal species of $\alpha$-syn found in PD patients are also present in LBs of other synucleinopathy-affected brains, including $\mathrm{AD}$ and multiple-system atrophy (MSA) (Duda et al. 2000; Giasson et al. 2000; Cavallarin et al. 2010). These observations are supported by in vitro data and animal models of PD in which overexpression of native or mutated forms of $\alpha$-syn show that aberrant species have an increased propensity to aggregate (Parihar et al. 2009; Koprich et al. 2010). Aggre- gation of $\alpha$-syn is also caused by genetic mutations. Although most cases of PD have no family history of disease, point mutations in the gene encoding $\alpha$-syn (SNCA; OMIM 163890) are linked to autosomal-dominant parkinsonism (PARK1, OMIM 168601) (Polymeropoulos et al. 1996, 1997; Kruger et al. 1998; Zarranz et al. 2004), as are duplications and triplications of the SNCA gene (PARK4, OMIM 605543) (Singleton et al. 2003; Chartier-Harlin et al. 2004), all of which present increased aggregation of $\alpha$-syn (Narhi et al. 1999; Li et al. 2001; Uversky 2007). Taken together, these observations led to the $\alpha$-syn burden hypothesis, which posits that sporadic PD results from the inability to clear $\alpha$-syn, whereas familial PD results from overproduction of normal $\alpha$-syn, mutations in $\alpha$-syn that prevent or slow clearance, or mutations in other proteins that normally assist in $\alpha$-syn clearance (McGeer and McGeer 2008). McGeer further hypothesized that disease can be eliminated with the reduction of $\alpha$-syn production or prevention of $\alpha$-syn aggregation. Thus, vaccines currently being developed for PD, target $\alpha$-syn in order to increase clearance of aggregated and aberrant forms of the protein. However, because evidence supports a nonneuronal cell autonomous theory for PD progression whereby neuroinflammation is strongly implicated (Dawson 2008), immunotherapeutic strategies also incorporate means by which to attenuate the neuroinflammatory component.

Furthermore, reactive oxygen species produced by activated microglia increases nitration of $\alpha$-syn and neuronal cell death (Shavali et al. 2006); and in turn, immune $\mathrm{T}$ cells that recognize nitrated $\alpha$-syn ( $\mathrm{N}$ - $\alpha$-syn) enhance the neurotoxic activities of microglia in the acute 1-methyl-4-phenyl-1,2,3,6-tetrahydropyridine (MPTP) mouse model of nigrostriatal degeneration (Reynolds et al. 2008b). Activated T cells and $\mathrm{B}$ cells are then able to enter the CNS more readily and migrate to the site of neuronal injury (Aloisi et al. 1999; McGeer and McGeer 2003; Olson and Miller 2004). Indeed, increased $\mathrm{BBB}$ permeability is found in both $\mathrm{AD}$ and $\mathrm{PD}$, allowing for increased lymphocytic ingress (Rogers et al. 1988; Farkas et al. 2000; Togo et al. 
2002; Desai et al. 2007). In this way, activated innate immune cells of the CNS can affect the adaptive immune system in the periphery and recruit cells to the CNS. However, another way in which the adaptive immune system may be activated during neurodegeneration is through the escape of CNS proteins into the periphery. Indeed, aberrant species of disease-specific proteins, including phosphorylated $\alpha$-syn, are present in tissues outside the CNS in PD patients (Beach et al. 2010). The occurrence of these aberrant forms of $\alpha$-syn in the periphery, such as the gastrointestinal tract and draining cervical lymph nodes, presents a possible means for exposure to the protein and subsequent activation of the adaptive immune system.

\section{ADAPTIVE IMMUNITY IN PD}

From an earlier Perspectives in Biology and Medicine (Johns Hopkins University Press), Abramsky and colleagues broached the possibility that PD may arise from autoimmune blockade of striatal dopamine receptor function (Abramsky and Litvin 1978). Although clinical evidence has not sufficiently supported this possibility, many studies have implicated the adaptive immune system in PD progression. With high glia/neuron ratios of 3:1 in the brain (Lawson et al. 1990) and the density of microglia contained within the $\mathrm{SN}$, the highest of any region in the brain (Kim et al. 2000), any increase in the inflammatory status of the patient may additively, if not synergistically amplify neuroinflammation. Since 1988, when McGeer and colleagues found HLA-DR-positive (activated) microglia phagocytosing-free neuromelanin in post mortem PD SN (McGeer et al. 1988a), activated microglial consistently have been observed in PD patients, whereas others have shown higher expression levels of polymorphic major histocompatibility complex (MHC) class II (MHC II) molecules, HLA-DR and HLA-DQ, expressed by monocytes in the CSF and peripheral blood of PD patients compared with controls (McGeer et al. 1988b; Fiszer et al. 1994a; Lampe et al. 2003). More recently, genome-wide association studies (GWASs) of PD patients (Hamza et al. 2010; Saiki et al.
2010; Nalls et al. 2011; Puschmann et al. 2011; Simon-Sanchez et al. 2011), including a metaanalysis of the GWASs (Nalls et al. 2011), verified an increased relative risk for PD and expression of HLA-DR or HLA-DQ MHC II molecules, leading to the designation of HLA-DRA as PARK18 (Hamza et al. 2010). Increased susceptibility to PD owing to MHC II molecules could reflect increased neuroinflammation associated with up-regulation of those molecules or alternatively, could represent immune responses to self- or weak nonself-antigens. Activated microglia and monocytes in PD brains and CFS secrete proinflammatory and neurotoxic cytokines and chemokines that disrupt the $\mathrm{BBB}$ and attract lymphocytes to the site of neuronal injury. Indeed, levels of IL-1 $\beta$, IL-6, and TNF- $\alpha$ are elevated in the CFS of PD patients (Blum-Degen et al. 1995; GonzalezScarano and Baltuch 1999), and intercellular adhesion molecule-1 (ICAM-1)-positive glia are also increased in the SN of PD brains (Miklossy et al. 2006). Together, these data support the hypothesis that activation of cells of the innate immune system, such as microglia and monocytes, directly contribute to the pathobiology of PD. Furthermore, it has been shown that these cells are activated by overexpression of $\alpha$-syn or aberrant forms of $\alpha$-syn. Aberrant posttranslational modifications of $\alpha$-syn, such as nitration (N- $\alpha$-syn), can be found in LB inclusions of PD brains (Giasson et al. 2000) and cause the protein to aggregate more readily (Uversky et al. 2005). Aggregated $\alpha$-syn activates microglia (Zhang et al. 2005), which have been shown to produce nitric oxide and superoxide in mice and inducible nitric oxide synthase (iNOS) in humans, which increases nitration of $\alpha$-syn and perpetuates the proinflammatory innate immune response in $\mathrm{PD}$ (Fig. 1) (Hunot et al. 1996; Gao et al. 2008). Nitrated $\alpha$-syn in turn amplifies activation of microglia and antigen-presenting cells that correspondingly up-regulate both humoral and cell-mediated responses to nitrated $\alpha$-syn in the MPTP model (Benner et al. 2008).

Although autoantibodies against dopamine neuron antigens are present in sera and CSF of PD patients (McRae-Degueurce et al. 1988; 
R.L. Mosley et al.

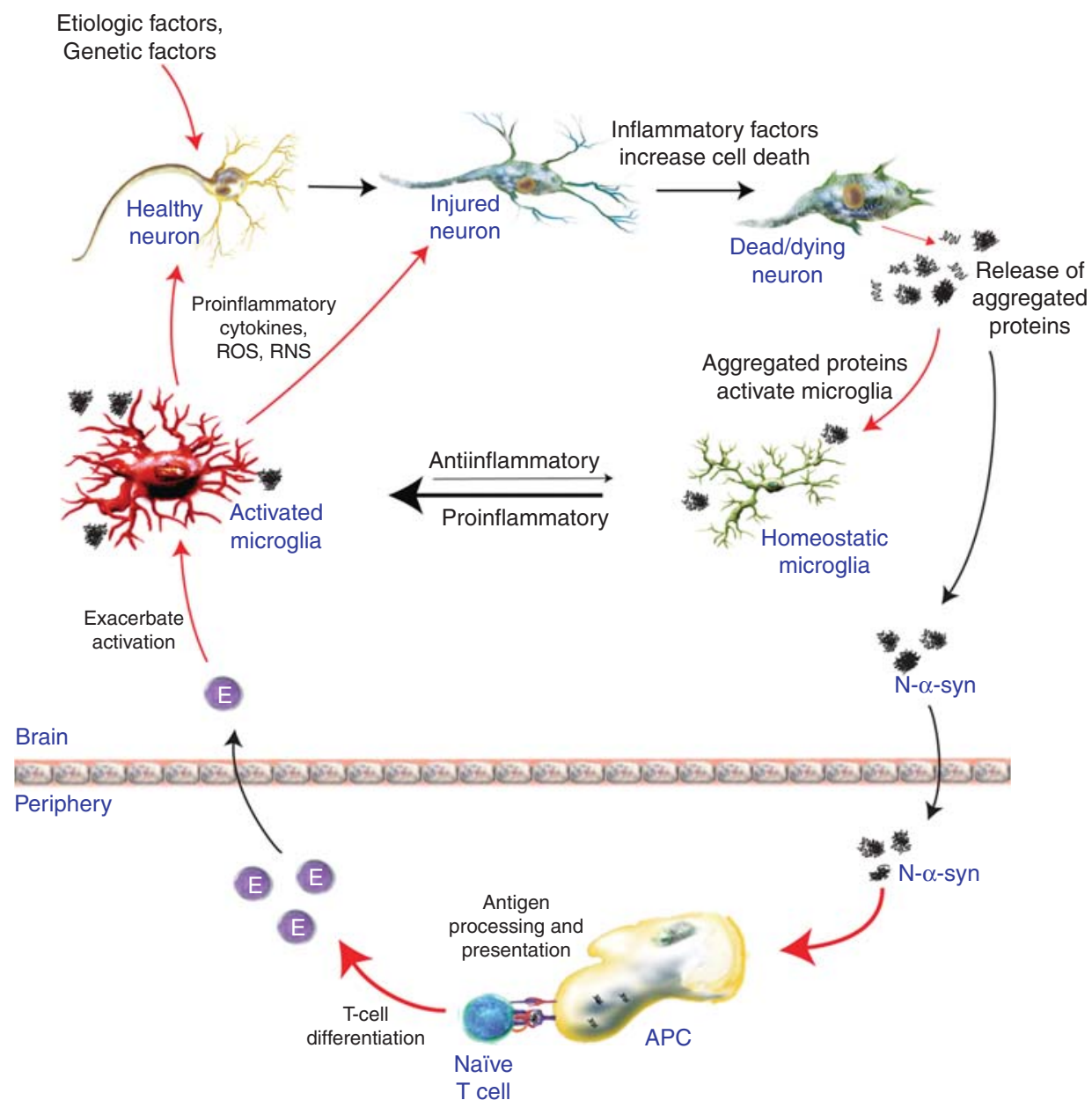

Figure 1. Immune contributions to PD pathogenesis. Reactive microgliosis is a prominent feature of neurodegenerative diseases such as PD. Microglia are sensitive to changes in their microenvironment, which include factors released from damaged/dying neurons such as modified and aggregated proteins (i.e., $\alpha$-synculein found in Lewy bodies). Activated microglia may respond to these factors by secreting proinflammatory factors and ROS/ RNS that perpetuate neuronal injury and death. Furthermore, modified $\alpha$-synuclein (e.g., N- $\alpha$-synunclein) may drain to the periphery where an adaptive immune response is mounted against these antigens. Although increased numbers of lymphocytes are found in the SN of PD patients' brains, their exact role is not yet known. However, experimental evidence suggests that effector T-cell (E) responses contribute to microglia activation and accelerate neurodegeneration. Taken together, the innate and adaptive immune responses operative in PD may accelerate neurodegeneration and are an active area of research.

Dahlstrom et al. 1990; Kunas et al. 1995), the role of the humoral adaptive immune system has only recently begun to be investigated in depth. In addition to a variety of antibodies directed against globally expressed tissue antigens such as heat shock protein (HSP)-65 and HSP-70 (Fiszer et al. 1996), PD patients also show brain-associated autoantibodies including those directed against, GM1, S100B, glial fibrillar acidic protein (GFAP), NGF, neurofilament, myelin basic protein, tau, $A \beta$, and neuronal calcium channels, as well as $\alpha$-syn and its modified and fibriliary forms (Elizan et al. 1983; Karcher et al. 1986; Appel et al. 1994; 
Terryberry et al. 1998; Poletaev et al. 2000; Zappia et al. 2002; Papachroni et al. 2007; Gruden et al. 2011; Yanamandra et al. 2011). Immunohistochemical staining of tissues from idiopathic and familial PD patients show dopaminergic neurons within the SN bind IgG, but not IgM, whereas tissues from age-matched controls and nonnigral control tissues show no detectable bound immunoglobulins (Orr et al. 2005). In one study, IgG reacted with $30 \%$ of the dopaminergic neurons within the nigra, and yielded positive correlations with numbers of $\mathrm{MHC} \mathrm{II}^{+}$and $\mathrm{CD}^{+} 4^{+}$(Fc $\left.\gamma \mathrm{RI}\right)$ reactive microglia, yet yielded a negative correlation with disease duration. In PD patients, approximately $4 \%$ of the pigmented neurons contained Lewy bodies and all pigmented, Lewy bodycontaining neurons showed detectable IgG and $\alpha$-syn within inclusions. This pattern of antibody reactivity was consistent with activated microglia and destruction of dopaminergic neurons in PD. Together these data suggest that endogenous antibodies of unknown specificity have the capacity to cross the $\mathrm{BBB}$ and bind cognate antigens expressed by dopaminergic neurons. Of interest, deletion of the Fc $\gamma \mathrm{R}$ by genetic ablation inhibits microglial activation and dopaminergic cell death in animal models of PD (He et al. 2002). Moreover, levels of antibodies to $\alpha$-syn and catecholamine-derived melanin (neuromelanin) are increased in PD patients with antineuromelanin immunoglobulin binding shown to be more active in early disease (Double et al. 2009). Opsonization of cells or damaged neurons with antibody, targets the cells for phagocytosis and degradation by phagocytic macrophages, and also can activate the complement system, a major mediator of immune/inflammatory reactions. Interestingly, activation of the complement system may also be involved in neuronal death. Microglia are the only cells within the SN that express the initial recognition component of complement, C1q (Depboylu et al. 2011). Moreover, compared with controls, PD patients show increased areas of C1q-opsonized extracellular depositions of neuromelanin within the parenchyma, and C1q-expressing phagocytic microglia surround those areas, as well as cells around the luminal surfaces of the vasculature that express neuromelanin and $\mathrm{C} 1 \mathrm{q}$, suggesting a role for antiself antibodies and Clq-mediated clearing pathways in PD.

Along with activated microglia and astrocytes, T cells may also comprise components of PD pathobiology, although the mechanism(s) by which they effect disease remains enigmatic. Early autopsy evidence within the SN of PD patients showed increased numbers of $\mathrm{CD}^{+} \mathrm{T}$ cells in close proximity to activated microglia and degenerating neurons (McGeer et al. 1988a). More recently, both $\mathrm{CD}^{+}$and $\mathrm{CD} 8^{+}$ $\mathrm{T}$ cells have been discovered within the SN of PD patients (Brochard et al. 2009). Although a dysfunctional BBB in PD patients may show some leakiness (Kortekaas et al. 2005), this may not be sufficient to allow unrestricted lymphocyte infiltration because CD4/CD8 ratios were 1:4.8 (Brochard et al. 2009) compared with the typical 2:1 ratio expected for peripheral T cells performing surveillance functions. Thus, the mechanism by which these $\mathrm{T}$ cells gain access to the SN, their activation state, and their function are questions that remain to be answered.

Peripheral immune aberrations, particularly in lymphocyte subsets, are abundant in PD patients. Total numbers of lymphocytes have been shown to be diminished by $17 \%$, whereas $\mathrm{CD} 19^{+} \mathrm{B}$ cells are diminished as much as $35 \%$ and $\mathrm{CD}^{+} \mathrm{T}$ cells are diminished by 22\% (Bas et al. 2001). Among CD3 ${ }^{+} \mathrm{T}$ cells, numbers of $\mathrm{CD}^{+} \mathrm{T}$ cells have been shown to be diminished by $31 \%$, whereas numbers of $\mathrm{CD}^{+} \mathrm{T}$ cells are not significantly changed. A greater loss of naïve helper $\mathrm{CD}^{+} \mathrm{T}$ cells $\left(\mathrm{CD} 45 \mathrm{RA}^{+}\right)$and either unchanged or increased levels of effector/memory helper T-cell subset $\left(\mathrm{CD} 29^{+}\right.$or $\left.\mathrm{CD} 45 \mathrm{R}^{+}\right)$have also been observed. Selective loss of $\mathrm{CD} 4{ }^{+} \mathrm{CD} 45 \mathrm{RA}^{+}$cells are also detected in other neuoropathological-associated disorders such as MS and Down's syndrome, suggesting a common immunological abnormality in neurological disorders (Fiszer et al. 1994a; Crucian et al. 1995). Increased frequencies of activated $\mathrm{CD}^{+}{ }^{+} \mathrm{T}$ cells expressing Fas (Hisanaga et al. 2001) and increased IFN- $\gamma$ producing Th1 cells, decreased IL-4-producing 
Th2 cells, and a decrease in $\mathrm{CD} 4{ }^{+} \mathrm{CD} 25^{+} \mathrm{T}$ cells have been found in the peripheral blood of PD patients (Baba et al. 2005), whereas circulating IL-15, RANTES, and IL-10 are significantly elevated in PD patients compared with controls (Rentzos et al. 2007, 2009). Evidence of increased mutual coexpression of CD4 and CD8 by $\mathrm{CD} 45 \mathrm{R} 0^{+} \mathrm{T}$ cells, increased expression of CD25 ( $\alpha$ chain of the high-affinity IL-2 receptor) and TNF- $\alpha$ receptors, and diminished expression of IFN- $\gamma$ receptors suggest that these T-cell subsets from PD patients are indeed activated. In addition to T cells that express $\alpha$ and $\beta$ chains of the T-cell receptor (TCR $\alpha \beta^{+}$T cells), elevated frequencies of T-cell populations expressing $\gamma$ and $\delta$ chains of the T-cell receptor (TCR $\gamma \delta^{+} \mathrm{T}$ cells) also have been found in the CSF of PD patients (Fiszer et al. 1994b) and are thought to play a regulatory role in CNS inflammation (Ponomarev and Dittel 2005; Bennett and Stuve 2009; Blink and Miller 2009). Moreover, a large proportion of the TCR $\gamma \delta^{+} \mathrm{T}$ cells also express CD25, suggesting these CSF-obtained $\mathrm{T}$ cells are preferentially activated in $\mathrm{PD}$ patients (Fiszer et al. 1994b). One way in which the adaptive immune system could be mobilized to infiltrate the CNS during PD is through the drainage of aberrant forms of $\alpha$-syn into the lymphatic system where the protein could activate lymphocytes. Indeed, in MPTP-intoxicated mice, $\alpha$-syn drains to cervical lymph nodes where it activates antigen-presenting cells and $T$ cells (Benner et al. 2008). An influx of $\alpha$-synspecific Th1 or Th17 effector T cells into the brain during PD could increase the inflammatory phenotype and neurotoxic response of microglia near dopaminergic neurons by increasing the concentration of proinflammatory molecules in the SN (Reynolds et al. 2010). Taken together, increased frequencies of memory and activated peripheral T-cell subsets, as well as those cells within the nigra of PD patients, suggest putative roles of $\mathrm{T}$ cells in disease progression, if not PD etiology. Although those roles have yet to be delineated, activated effector $\mathrm{T}$ cells $\left(\mathrm{T}_{\text {eff }}\right)$ or regulatory $\mathrm{T}$ cells $\left(\mathrm{T}_{\text {reg }}\right)$, the latter also showing an effector/memory T-cell phenotype, may migrate to the foci of inflammation in $\mathrm{PD}$ patients and either exacerbate or attenuate
PD-associated neuroinflammatory responses and neurodegeneration. Thus, $\mathrm{T}_{\text {reg }}$ have the capacity to keep the disorder in check during the asymptomatic phase, whereas $T_{\text {eff }}$ can accelerate disease progression (Fig. 1). Whether T-cell aberrations in PD patients reflect specifically activated effector or regulatory T-cell subsets and to what antigen(s) those T cells are induced, require answers to develop more precise immunebased therapeutic strategies.

\section{ADAPTIVE IMMUNITY FOR THERAPEUTIC GAIN IN PD}

It is likely that the adaptive immune system's response to disease in the CNS is similar in a range of neurodegenerative diseases. Thus, therapeutic strategies aimed at modulating the immune response during disease may be applicable to several neurodegenerative diseases. Here we will discuss recent approaches taken to modulate the adaptive immune system for disease therapy.

$\mathrm{T}_{\text {reg }}$ are an important subset of CD4 ${ }^{+} \mathrm{T}$ cells that are known to maintain self-tolerance, prevent autoimmunity, and regulate immune homeostasis by attenuating excessive inflammation caused by pathogens or injury (Sakaguchi et al. 1995; Cederbom et al. 2000; Kipnis et al. 2002; Hori et al. 2003; Sakaguchi 2004; Coombes et al. 2005; Kim et al. 2007; Bourreau et al. 2009). They are identified by the expression of CD4 and CD25 cell-surface markers and by the transcription factor forkhead box P3 (FoxP3) in mice (Hall et al. 1990; Fontenot et al. 2003; Hori et al. 2003), and the expression of FOXP3, CD4, CD25, CD39, CD49d, and a lack of CD127 in humans (Fletcher et al. 2009; Kleinewietfeld et al. 2009). Although naturally occurring $\mathrm{T}_{\text {reg }}$ mature in the thymus, naïve $\mathrm{CD} 4{ }^{+}$-stimulated $\mathrm{T}$ cells in the periphery can be polarized into an inducible $\mathrm{T}_{\text {reg }}\left(\mathrm{iT}_{\text {reg }}\right)$ phenotype under certain conditions. For example, TGF- $\beta$, IL-2, IL-10, and all-trans retinoic acid are known to polarize $\mathrm{T}$ cells to $\mathrm{iT}_{\text {reg }}$ (Zheng et al. 2007, 2008; Khattar et al. 2009; Lee et al. 2009b), whereas histone deacetylase inhibitors are known to increase proliferation and suppressor activity of $\mathrm{T}_{\text {reg }}$ (Tao et al. 2007; Johnson 
et al. 2008; Lucas et al. 2009; Saouaf et al. 2009). In vitro studies have shown that $\mathrm{T}_{\text {reg }}$ can suppress $\mathrm{T}_{\text {eff }}$ responses via cell-to-cell contact $(\mathrm{Ce}-$ derbom et al. 2000) and soluble factors (Wahl et al. 2004). $\mathrm{T}_{\text {reg }}$ can also inhibit the adaptive immune system indirectly by suppressing antigen presentation by APCs (Maloy et al. 2003). In the brain, $\mathrm{T}_{\text {reg }}$ promote neurotrophic support by inducing astrocytes to increase expression of brain-derived neurotrophic factor (BDNF) and glial cell-derived neurotrophic factor (GDNF) (Benner et al. 2004; Reynolds et al. 2007), and may promote glutamate clearance (Garg et al. 2008). Dysfunctional and reduced frequencies of $\mathrm{T}_{\text {reg }}$ are associated with several autoimmune diseases (Costantino et al. 2008), including multiple MS (Venken et al. 2008; Fletcher et al. 2009; Royal et al. 2009; Koen 2010), type 1 diabetes (Glisic et al. 2009), inflammatory skin disorders (Fujimura et al. 2008), autoimmune myasthenia gravis (Mu et al. 2009), and rheumatoid arthritis (Cao et al. 2003) as well as chronic inflammatory diseases such as systemic lupus erythematosus (Horwitz 2008; Venigalla et al. 2008; Barreto et al. 2009), asthma (Xue et al. 2007), inflammatory bowel disease (Bourreau et al. 2009), and immune dysregulation polyendocrinopathy enteropathy X-linked (IPEX) syndrome, which is caused by a genetic mutation in the transcription factor FOXP3 (Bennett et al. 2001). Furthermore, $T_{\text {reg }}$ are being investigated for therapeutic use in several of these diseases (Gonzalez-Rey et al. 2006; Brusko et al. 2008; Haas et al. 2009; Putnam et al. 2009; Vandenbark et al. 2009).

In our own works, $\mathrm{T}_{\text {reg }}$ can migrate from the periphery to the site of HIV-1-induced neuroinflammation in a mouse model of HIV-1 encephalitis (unpubl.). Adoptive transfer of activated $\mathrm{CD} 4{ }^{+} \mathrm{CD} 25^{+} \mathrm{T}_{\text {reg }}$ to HIV-1 encephalitic mice is neuroprotective (Liu et al. 2009). This study showed that adoptively transferred $\mathrm{T}_{\text {reg }}$ attenuated microgliosis and astrogliosis, increased expression of BDNF and GDNF expression, and down-regulated proinflammatory cytokines, oxidative stress, and viral replication, whereas effector $\mathrm{CD}^{+}{ }^{+} \mathrm{T}$ cells were not therapeutic (Liu et al. 2009). $\mathrm{T}_{\text {reg }}$ inhibit release of viral particles from HIV-1-infected human mononuclear phagocytes (MP), kill infected cells, and induce phenotypic changes in MP (Huang et al. 2010). Up-regulation of the antiviral ubiquitin-like protein, interferon-stimulated gene 15 (ISG15) was concordant with the decrease in viral release from MP, and implicating caspase-3 and granzyme/perforin pathways in MP killing. Finally, it was shown that $\mathrm{T}_{\text {reg }}$ induce the phenotypic switch of MP from the neurotoxic MI phenotype to the more neurotrophic M2 phenotype with the downregulation of iNOS and up-regulation of arginase 1 . In the MPTP mouse model, $\mathrm{T}_{\text {reg }}$ control microglia function by suppressing reactive oxygen species production and NFKB activation via mechanisms that modulate redox enzymes, cell migration, and phagocytosis (Reynolds et al. 2007, 2009, 2010). Furthermore, the adoptive transfer of $\mathrm{T}_{\text {reg }}$ leads to $>90 \%$ protection of dopaminergic neurons within the nigrostriatal system, whereas adoptive transfer of Th1 or Th17 $\mathrm{T}_{\text {eff }}$ exacerbate neuronal degeneration and cotransfer of $\mathrm{T}_{\text {reg }}$ with Th1 or Th17 increases the protective effect (Reynolds et al. 2010). Together, these data suggest that $T_{\text {reg }}$ may be used to suppress the activity of the innate and adaptive immune responses operative in HIV-1 neurodegeneration and PD pathogenesis by transforming the neurotoxic phenotype of activated microglia, Th1, and Th17 cells.

\section{PROSPECTS TOWARD EFFECTIVE IMMUNOTHERAPEUTICS FOR PD}

Over the past decade, immunization strategies have been proposed to combat disease progression for neurodegenerative disorders, but principally for AD. Such strategies readily induce humoral immune responses against misfolded protein aggregates to facilitate their clearance in diseased brain tissue. However, such activities also induce robust adaptive immunity against the same misfolded proteins and serve to accelerate disease progression. This is precipitated by induced effector T-cell responses that can lead to encephalitis and profound neural injuries, and has led investigators to search for mechanisms that attenuate such adaptive neurotoxic immune responses. We posit that the 
R.L. Mosley et al.
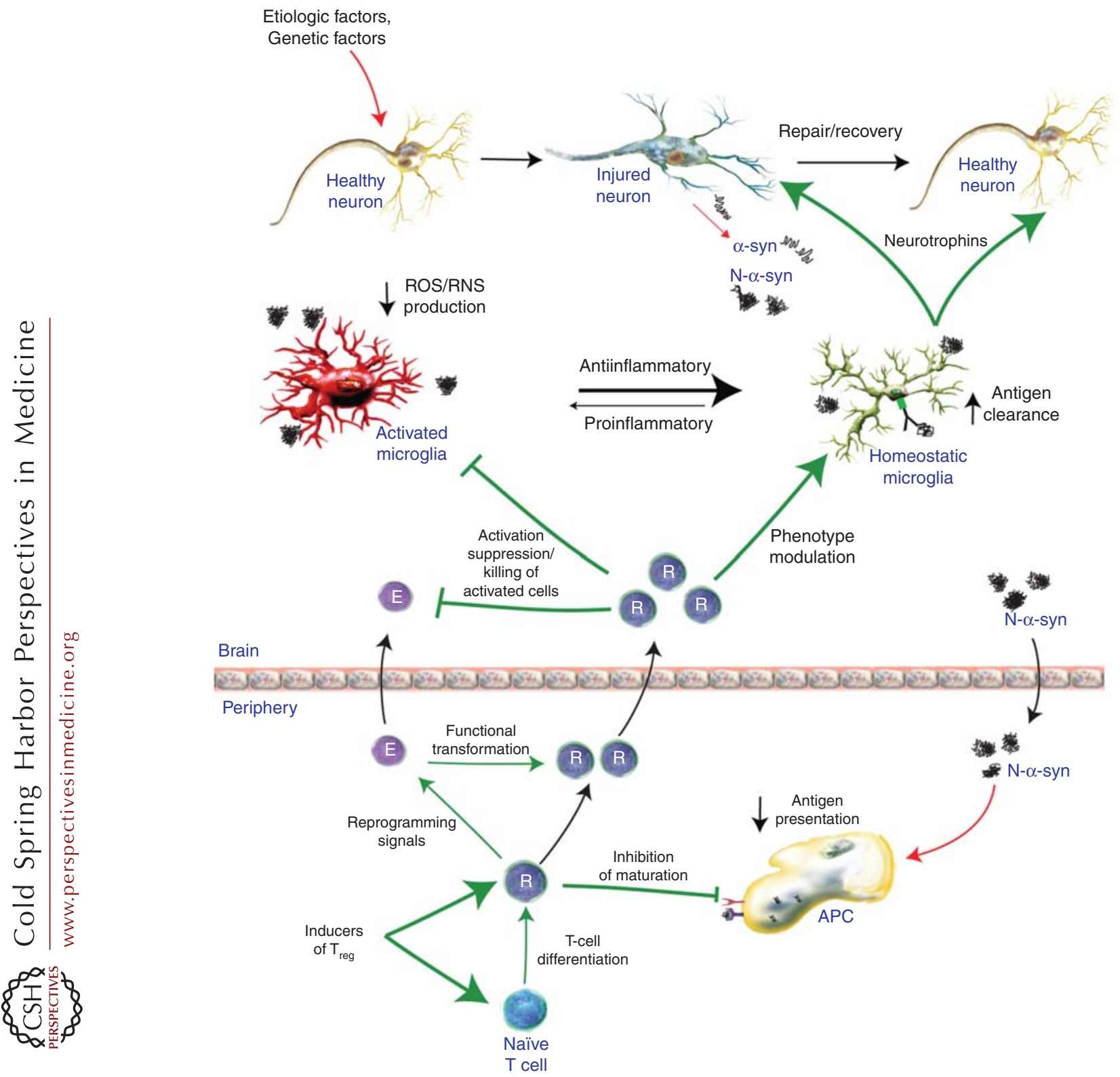

Figure 2. Adaptive immunity for therapeutic gain. Regulatory $T$ cells $\left(\mathrm{T}_{\text {reg }}, \mathrm{R}\right)$ work to control excessive inflammation and may be harnessed to control neuroinflammation in PD and other neurodegenerative diseases. $\mathrm{T}_{\text {reg }}$ can modulate microglia and other immune cells away from proinflammatory responses to anti-inflammatory/ homeostatic functions. Therefore, strategies aimed at inducing, boosting, or reprogramming $\mathrm{T}_{\text {reg }}$ responses (e.g., functional transformation of $\mathrm{T}_{\text {eff }}[\mathrm{E}]$ to $\mathrm{T}_{\text {reg }}$, increasing $n \mathrm{~T}_{\text {reg }}$ numbers, or activating $\mathrm{T}_{\text {reg }}$ in an antigen-specific manner) show promise as possible disease-modifying therapies. $\mathrm{T}_{\text {reg }}$ can modulate immune responses via several mechanisms, including suppressing microglia activation, inducing microglia phenotypic switching (toward anti-inflammatory), killing activated cells (e.g., $\mathrm{T}_{\text {eff }}$ and microglia), and inhibition of APC maturation and antigen presentation. All together, $\mathrm{T}_{\text {reg }}$ may suppress innate and adaptive proinflammatory, neurotoxic immune responses and boost homeostatic, neurotrophic immune responses resulting in slowing of neurodegeneration and allowing repair of damaged neurons. Such strategies may help to slow or halt the progression of PD. 
$\mathrm{T}_{\text {reg }}$ responses in $\mathrm{PD}$ are dysfunctional during advanced disease states. As such, this serves to shift the balance from regulatory to effector T-cell activities, and yields an inability to attenuate ongoing neurotoxic inflammatory events (Fig. 2). If clearance of misfolded proteins can be achieved with subsequent immune modulation and restoration of $\mathrm{T}_{\text {reg }}$ responses, improved therapeutic outcomes for neuronal protection would be realized. This may be achieved through advances in immune regulation used to achieve a homeostatic glial response for therapeutic gain.

\section{SUMMARY AND CONCLUSIONS}

No doubt, the role of inflammation in PD is now well appreciated. This is supported by data seen in a growing number of laboratory and animal investigations as well as in human studies. Inflammation is linked to the extracellular appearance of brain protein modifications and aberrant protein misfolding, which remain prominent hallmarks of PD-associated dopaminergic neurodegeneration. During disease, dopaminergic neurons accumulate $\alpha$-synuclein together with other misfolded proteins seen as intracellular Lewy body inclusions. On injury or death, neurons release these proteins to the surrounding neuroenvironment and the modified proteins find their way to the peripheral lymphatic system. In an attempt to clear and digest cellular debris, microglia and blood-borne macrophages infiltrate sites of neuronal injury and death and convert to a proinflammatory activated state. Misfolded and modified $\alpha$ synuclein species draining from these sites also have the capability to activate antigen-presenting cells in peripheral lymphoid tissues inducing effector neurotoxic T-cell responses. This normally serves to facilitate debris clearance and repair functions. Indeed, under steady-state conditions and early in disease, activated microglia and adaptive immune responses are limited. Nonetheless, as disease becomes more robust, activated microglia are seen in abundant numbers removed from proximate areas of neuronal death. This may be attributable to the failure of activated microglia to return to a homeostatic state. Thus, disease-affected microglia are in a constant activation flux, oscillating between homeostatic and activation states. Interestingly, whereas this cell maintains an activated amoeboid phenotype, microglial functional profiles can encompass a broad range of responses that range from an M1 (proinflammatory neurotoxic) to M2 (anti-inflammatory neuroprotective) activities. Such evolution in cell function may be driven by the deposition and release of nondegradable modified proteins or by infiltrating $\mathrm{T}$ lymphocytes. Once modified protein species enters the peripheral lymphoid tissues, activate antigen-presenting cells, and are presented as neoepitopes, adaptive immune responses are induced. Subsequent induction of effector T-cell-mediated responses may profoundly affect microglial states or directly kill neurons. As disease evolves, these responses emerge from a well-regulated neuroprotective state to loss of regulatory function and disease. In this scenario, the engagement of therapeutic strategies that dampen inflammatory and neurotoxic profiles by induction or repair of aberrant regulatory $\mathrm{T}$-cell responses could provide a means to reverse the neurodegenerative process. Thus, modulation of inflammatory responses for therapeutic gain remains an ever-pressing directive to improve disease outcomes.

\section{REFERENCES}

* Reference is also in this collection.

Abramsky O, Litvin Y. 1978. Autoimmune response to dopamine-receptor as a possible mechanism in the pathogenesis of Parkinson's disease and schizophrenia. Perspect Biol Med 22: 104-114.

Aloisi F, Ria F, Columba-Cabezas S, Hess H, Penna G, Adorini L. 1999. Relative efficiency of microglia, astrocytes, dendritic cells and $\mathrm{B}$ cells in naive $\mathrm{CD} 4^{+} \mathrm{T}$ cell priming and Th1/Th2 cell restimulation. Eur J Immunol 29: 2705-2714.

Appel SH, Smith RG, Alexianu M, Engelhardt J, Mosier D, Colom L, Stefani E. 1994. Neurodegenerative disease: Autoimmunity involving calcium channels. Ann NY Acad Sci 747: 183-194.

Arai H, Furuya T, Mizuno Y, Mochizuki H. 2006. Inflammation and infection in Parkinson's disease. Histol Histopathol 21: 673-678.

Baba Y, Kuroiwa A, Uitti RJ, Wszolek ZK, Yamada T. 2005. Alterations of T-lymphocyte populations in Parkinson disease. Parkinsonism Relat Disord 11: 493-498. 
R.L. Mosley et al.

Barreto M, Ferreira RC, Lourenço L, Moraes-Fontes MF Santos E, Alves M, Carvalho C, Martins B, Andreia R, Viana JF, et al. 2009. Low frequency of $\mathrm{CD} 4^{+} \mathrm{CD} 25^{+} \mathrm{T}_{\text {reg }}$ in SLE patients: A heritable trait associated with CTLA4 and TGF $\beta$ gene variants. BMC Immunol 10: 5 .

Bas J, Calopa M, Mestre M, Mollevi DG, Cutillas B, Ambrosio S, Buendia E. 2001. Lymphocyte populations in Parkinson's disease and in rat models of parkinsonism. J Neuroimmunol 113: 146-152.

Basith S, Manavalan B, Lee G, Kim SG, Choi S. 2011. Tolllike receptor modulators: A patent review (2006-2010). Expert Opin Ther Pat 21: 927-944.

Beach TG, Adler CH, Sue LI, Vedders L, Lue L, White CL III, Akiyama H, Caviness JN, Shill HA, Sabbagh MN, et al. 2010. Multi-organ distribution of phosphorylated $\alpha$-synuclein histopathology in subjects with Lewy body disorders. Acta Neuropathol 119: 689-702.

Benner EJ, Mosley RL, Destache CJ, Lewis TB, JacksonLewis V, Gorantla S, Nemachek C, Green SR, Przedborski S, Gendelman HE. 2004. Therapeutic immunization protects dopaminergic neurons in a mouse model of Parkinson's disease. Proc Natl Acad Sci 101: 9435-9440.

Benner EJ, Banerjee R, Reynolds AD, Sherman S, Pisarev VM, Tsiperson V, Nemachek C, Ciborowski P, Przedborski S, Mosley RL, et al. 2008. Nitrated $\alpha$-synuclein immunity accelerates degeneration of nigral dopaminergic neurons. PLoS One 3: e1376.

Bennett JL, Stuve O. 2009. Update on inflammation, neurodegeneration, and immunoregulation in multiple sclerosis: Therapeutic implications. Clin Neuropharmacol 32: $121-132$.

Bennett CL, Christie J, Ramsdell F, Brunkow ME, Ferguson PJ, Whitesell L, Kelly TE, Saulsbury FT, Chance PF, Ochs HD. 2001. The immune dysregulation, polyendocrinopathy, enteropathy, X-linked syndrome (IPEX) is caused by mutations of FOXP3. Nat Gen 27: 20-21.

Blink SE, Miller SD. 2009. The contribution of $\gamma \delta$ T cells to the pathogenesis of EAE and MS. Curr Mol Med 9: $15-22$.

Blum-Degen D, Muller T, Kuhn W, Gerlach M, Przuntek H, Riederer P. 1995. Interleukin-1 ßand interleukin-6 are elevated in the cerebrospinal fluid of Alzheimer's and de novo Parkinson's disease patients. Neurosci Lett 202: $17-20$.

Bourreau E, Ronet C, Darcissac E, Lise MC, Sainte Marie D, Clity E, Tacchini-Cottier F, Couppie P, Launois P. 2009. Intralesional regulatory T-cell suppressive function during human acute and chronic cutaneous leishmaniasis due to Leishmania guyanensis. Infect Immun 77: 14651474.

Brochard V, Combadière B, Prigent A, Laouar Y, Perrin A, Beray-Berthat V, Bonduelle O, Alvarez-Fischer D, Callebert J, Launay JM, et al. 2009. Infiltration of CD4 $4^{+}$lymphocytes into the brain contributes to neurodegeneration in a mouse model of Parkinson disease. J Clin Invest 119: 182-192.

Brusko TM, Putnam AL, Bluestone JA. 2008. Human regulatory T cells: Role in autoimmune disease and therapeutic opportunities. Immunol Rev 223: 371-390.

Cao D, Malmström V, Baecher-Allan C, Hafler D, Klareskog L, Trollmo C. 2003. Isolation and functional characterization of regulatory $\mathrm{CD} 25$ brightCD $4^{+} \mathrm{T}$ cells from the target organ of patients with rheumatoid arthritis. Eur $J$ Immunol 33: 215-223.

Cavallarin N, Vicario M, Negro A. 2010. The role of phosphorylation in synucleinopathies: Focus on Parkinson's disease. CNS Neurol Disord Drug Targets 9: 471-481.

Cederbom L, Hall H, Ivars F. 2000. $\mathrm{CD}^{+} \mathrm{CD}^{+} 5^{+}$regulatory $\mathrm{T}$ cells down-regulate co-stimulatory molecules on antigen-presenting cells. Eur J Immunol 30: 1538-1543.

Chao CC, Hu S, Kravitz FH, Tsang M, Anderson WR, Peterson PK. 1994. Transforming growth factor- $\beta$ protects human neurons against $\beta$-amyloid-induced injury. Molec Chem Neuropathol 23: 159-178.

Chartier-Harlin MC, Kachergus J, Roumier C, Mouroux V, Douay X, Lincoln S, Levecque C, Larvor L, Andrieux J, Hulihan M, et al. 2004. $\alpha$-Synuclein locus duplication as a cause of familial Parkinson's disease. Lancet 364: 1167-1169.

Coombes JL, Robinson NJ, Maloy KJ, Uhlig HH, Powrie F. 2005. Regulatory T cells and intestinal homeostasis. Immunol Rev 204: 184-194.

Costantino CM, Baecher-Allan CM, Hafler DA. 2008. Human regulatory T cells and autoimmunity. Eur J Immunol 38: 921-924.

Crucian B, Dunne P, Friedman H, Ragsdale R, Pross S, Widen R. 1995. Alterations in levels of $\mathrm{CD} 28^{-} / \mathrm{CD}^{+}$suppressor cell precursor and $\mathrm{CD} 45 \mathrm{RO}^{+} / \mathrm{CD}^{+}$memory $\mathrm{T}$ lymphocytes in the peripheral blood of multiple sclerosis patients. Clin Diagn Lab Immunol 2: 249-252.

Cserr HF, Knopf PM. 1992. Cervical lymphatics, the bloodbrain barrier and the immunoreactivity of the brain: A new view. Immunol Today 13: 507-512.

Cunningham C, Wilcockson DC, Boche D, Perry VH. 2005a. Comparison of inflammatory and acute-phase responses in the brain and peripheral organs of the ME7 model of prion disease. J Virol 79: 5174-5184.

Cunningham C, Wilcockson DC, Campion S, Lunnon K, Perry VH. 2005b. Central and systemic endotoxin challenges exacerbate the local inflammatory response and increase neuronal death during chronic neurodegeneration. J Neurosci 25: 9275-9284.

Dahlstrom A, Wigander A, Lundmark K, Gottfries CG, Carvey PM, McRae A. 1990. Investigations on auto-antibodies in Alzheimer's and Parkinson's diseases, using defined neuronal cultures. J Neural Transm Suppl 29: 195-206.

Dauer W, Przedborski S. 2003. Parkinson's disease: Mechanisms and models. Neuron 39: 889-909.

Dawson TM. 2008. Non-autonomous cell death in Parkinson's disease. Lancet Neurol 7: 474-475.

Depboylu C, Schafer MK, Arias-Carrion O, Oertel WH, Weihe E, Hoglinger GU. 2011. Possible involvement of complement factor $\mathrm{Clq}$ in the clearance of extracellular neuromelanin from the substantia nigra in Parkinson disease. J Neuropathol Exp Neurol 70: 125-132.

Desai BS, Monahan AJ, Carvey PM, Hendey B. 2007. Bloodbrain barrier pathology in Alzheimer's and Parkinson's disease: Implications for drug therapy. Cell Transplant 16: $285-299$.

Dickson D, Lee S, Mattiace L, Yen S, Brosnan C. 1993. Microglia and cytokines in neurological disease, with special reference to AIDS and Alzheimer's disease. Glia 7: 75-83. 
Double KL, Rowe DB, Carew-Jones FM, Hayes M, Chan DK, Blackie J, Corbett A, Joffe R, Fung VS, Morris J, et al. 2009. Anti-melanin antibodies are increased in sera in Parkinson's disease. Exp Neurol 217: 297-301.

Duda JE, Giasson BI, Chen Q, Gur TL, Hurtig HI, Stern MB, Gollomp SM, Ischiropoulos H, Lee VM, Trojanowski JQ. 2000. Widespread nitration of pathological inclusions in neurodegenerative synucleinopathies. Am J Pathol 157: 1439-1445.

Elizan TS, Casals J, Yahr MD. 1983. Antineurofilament antibodies in postencephalitic and idiopathic Parkinson's disease. J Neurol Sci 59: 341-347.

Elkabes S, DiCicco-Bloom EM, Black IB. 1996. Brain microglia/macrophages express neurotrophins that selectively regulate microglial proliferation and function. J Neurosci 16: $2508-2521$.

Engelhardt B, Ransohoff RM. 2005. The ins and outs of T-lymphocyte trafficking to the CNS: Anatomical sites and molecular mechanisms. Trends Immunol 26: 485495.

Farkas E, De Jong GI, Apro E, De Vos RA, Steur EN, Luiten PG. 2000. Similar ultrastructural breakdown of cerebrocortical capillaries in Alzheimer's disease, Parkinson's disease, and experimental hypertension. What is the functional link? Ann NY Acad Sci 903: 72-82.

Ferrari CC, Tarelli R. 2011. Parkinson's disease and systemic inflammation. Parkinsons Dis 2011: 436813.

Fiala M, Veerhuis R. 2009. Biomarkers of inflammation and amyloid- $\beta$ phagocytosis in patients at risk of Alzheimer disease. Exp Gerontol 45: 57-63.

Filias A, Theodorou GL, Mouzopoulou S, Varvarigou AA, Mantagos S, Karakantza M. 2011. Phagocytic ability of neutrophils and monocytes in neonates. BMC Pediatr 11: 29 .

Finch CE, Laping NJ, Morgan TE, Nichols NR, Pasinetti GM. 1993. TGF- $\beta 1$ is an organizer of responses to neurodegeneration. J Cell Biochem 53: 314-322.

Fiszer U, Mix E, Fredrikson S, Kostulas V, Link H. 1994a. Parkinson's disease and immunological abnormalities: Increase of HLA-DR expression on monocytes in cerebrospinal fluid and of $\mathrm{CD} 45 \mathrm{RO}^{+} \mathrm{T}$ cells in peripheral blood. Acta Neurol Scand 90: 160-166.

Fiszer U, Mix E, Fredrikson S, Kostulas V, Olsson T, Link H. 1994b. $\gamma \delta^{+}$T cells are increased in patients with Parkinson's disease. J Neurol Sci 121: 39-45.

Fiszer U, Fredrikson S, Czlonkowska A. 1996. Humoral response to hsp 65 and hsp 70 in cerebrospinal fluid in Parkinson's disease. J Neurol Sci 139: 66-70.

Fletcher JM, Lonergan R, Costelloe L, Kinsella K, Moran B, O'Farrelly C, Tubridy N, Mills KHG. 2009. CD39+ Foxp $3^{+}$regulatory $\mathrm{T}$ cells suppress pathogenic Th17 cells and are impaired in multiple sclerosis. J Immunol 183: 7602-7610.

Fontenot JD, Gavin MA, Rudensky AY. 2003. Foxp3 programs the development and function of $\mathrm{CD} 4{ }^{+} \mathrm{CD} 25^{+}$ regulatory T cells. Nat Immunol 4: 330-336.

Franklin BS, Ishizaka ST, Lamphier M, Gusovsky F, Hansen H, Rose J, Zheng W, Ataide MA, de Oliveira RB, Golenbock DT, et al. 2011. Therapeutical targeting of nucleic acid-sensing Toll-like receptors prevents experimental cerebral malaria. Proc Natl Acad Sci 108: 3689-3694.
Fujimura T, Okuyama R, Ito Y, Aiba S. 2008. Profiles of Foxp ${ }^{+}$regulatory $\mathrm{T}$ cells in eczematous dermatitis, psoriasis vulgaris and mycosis fungoides. Br J Dermatol 158: $1256-1263$.

Fujiwara H, Hasegawa M, Dohmae N, Kawashima A, Masliah E, Goldberg MS, Shen J, Takio K, Iwatsubo T. 2002. $\alpha$-Synuclein is phosphorylated in synucleinopathy lesions. Nat Cell Biol 4: 160-164.

Gao HM, Kotzbauer PT, Uryu K, Leight S, Trojanowski JQ, Lee VM. 2008. Neuroinflammation and oxidation/nitration of $\alpha$-synuclein linked to dopaminergic neurodegeneration. J Neurosci 28: 7687-7698.

Garg SK, Banerjee R, Kipnis J. 2008. Neuroprotective immunity: T cell-derived glutamate endows astrocytes with a neuroprotective phenotype. JImmunol 180: 3866-3873.

Giasson BI, Duda JE, Murray IV, Chen Q, Souza JM, Hurtig HI, Ischiropoulos H, Trojanowski JQ, Lee VM. 2000. Oxidative damage linked to neurodegeneration by selective $\alpha$-synuclein nitration in synucleinopathy lesions. Science 290: 985-989.

Giulian D, Baker TJ, Shih LC, Lachman LB. 1986. Interleukin 1 of the central nervous system is produced by ameboid microglia. J Exp Med 164: 594-604.

Glezer I, Simard AR, Rivest S. 2007. Neuroprotective role of the innate immune system by microglia. Neuroscience 147: 867-883.

Glisic S, Klinker M, Waukau J, Jailwala P, Jana S, Basken J, Wang T, Alemzadeh R, Hagopian W, Ghosh S. 2009. Genetic association of HLA DQB1 with $\mathrm{CD} 4{ }^{+} \mathrm{CD} 25^{+}$(high) T-cell apoptosis in type 1 diabetes. Genes Immun 10: 334-340.

Goldman M. 2007. Translational mini-review series on Tolllike receptors: Toll-like receptor ligands as novel pharmaceuticals for allergic disorders. Clin Exp Immunol 147: $208-216$.

Goldman JE, Yen SH, Chiu FC, Peress NS. 1983. Lewy bodies of Parkinson's disease contain neurofilament antigens. Science 221: 1082-1084.

Gonzalez-Rey E, Fernandez-Martin A, Chorny A, Delgado M. 2006. Vasoactive intestinal peptide induces $\mathrm{CD} 4^{+}$, $\mathrm{CD} 25^{+} \mathrm{T}$ regulatory cells with therapeutic effect in collagen-induced arthritis. Arthritis Rheum 54: 864-876.

Gonzalez-Scarano F, Baltuch G. 1999. Microglia as mediators of inflammatory and degenerative diseases. Annu Rev Neurosci 22: 219-240.

Grammas P, Ovase R. 2001. Inflammatory factors are elevated in brain microvessels in Alzheimer's disease. Neurobiol Aging 22: 837-842.

Greenwood J, Heasman SJ, Alvarez JI, Prat A, Lyck R, Engelhardt B. 2011. Review: Leucocyte-endothelial cell crosstalk at the blood-brain barrier: A prerequisite for successful immune cell entry to the brain. Neuropathol Appl Neurobiol 37: 24-39.

Griffin WS, Stanley LC, Ling C, White L, MacLeod V, Perrot LJ, White CLIII, Araoz C. 1989. Brain interleukin 1 and S-100 immunoreactivity are elevated in Down syndrome and Alzheimer disease. Proc Natl Acad Sci 86: 7611-7615.

Gruden MA, Sewell RD, Yanamandra K, Davidova TV, Kucheryanu VG, Bocharov EV, Bocharova OR, Polyschuk VV, Sherstnev VV, Morozova-Roche LA. 2011. Immunoprotection against toxic biomarkers is retained during 
R.L. Mosley et al.

Parkinson's disease progression. J Neuroimmunol 233: 221-227.

Haas J, Korporal M, Balint B, Fritzsching B, Schwarz A, Wildemann B. 2009. Glatiramer acetate improves regulatory T-cell function by expansion of naive $\mathrm{CD} 4^{+} \mathrm{CD} 25^{+}$ FOXP $3{ }^{+} \mathrm{CD} 31^{+}$T-cells in patients with multiple sclerosis. J Neuroimmunol 216: 113-117.

Hall BM, Pearce NW, Gurley KE, Dorsch SE. 1990. Specific unresponsiveness in rats with prolonged cardiac allograft survival after treatment with cyclosporine. III. Further characterization of the $\mathrm{CD}^{+}$suppressor cell and its mechanisms of action. J Exp Med 171: 141-157.

Hamza TH, Zabetian CP, Tenesa A, Laederach A, Montimurro J, Yearout D, Kay DM, Doheny KF, Paschall J, Pugh E, et al. 2010. Common genetic variation in the HLA region is associated with late-onset sporadic Parkinson's disease. Nat Genet 42: 781-785.

Hasegawa Y, Inagaki T, Sawada M, Suzumura A. 2000. Impaired cytokine production by peripheral blood mononuclear cells and monocytes/macrophages in Parkinson's disease. Acta Neurol Scand 101: 159-164.

He Y, Le WD, Appel SH. 2002. Role of Fcya receptors in nigral cell injury induced by Parkinson disease immunoglobulin injection into mouse substantia nigra. Exp Neurol 176: $322-327$.

Heese K, Hock C, Otten U. 1998. Inflammatory signals induce neurotrophin expression in human microglial cells. J Neurochem 70: 699-707.

Heesen C, Schulz KH, Fiehler J, Von der Mark U, Otte C, Jung R, Poettgen J, Krieger T, Gold SM. 2010. Correlates of cognitive dysfunction in multiple sclerosis. Brain Behav Immun 24: 1148-1155.

Hickey WF. 1999. Leukocyte traffic in the central nervous system: The participants and their roles. Semin Immunol 11: $125-137$.

Hickey WF. 2001. Basic principles of immunological surveillance of the normal central nervous system. Glia 36: $118-124$.

Hisanaga K, Asagi M, Itoyama Y, Iwasaki Y. 2001. Increase in peripheral CD4 bright ${ }^{+} \mathrm{CD} 8$ dull $^{+} \mathrm{T}$ cells in Parkinson disease. Arch Neurol 58: 1580-1583.

Holman DW, Klein RS, Ransohoff RM. 2011. The bloodbrain barrier, chemokines and multiple sclerosis. Biochim Biophys Acta 1812: 220-230.

Holmes C, Cunningham C, Zotova E, Woolford J, Dean C, Kerr S, Culliford D, Perry VH. 2009. Systemic inflammation and disease progression in Alzheimer disease. $\mathrm{Neu}$ rology 73: 768-774.

Hori S, Nomura T, Sakaguchi S. 2003. Control of regulatory T cell development by the transcription factor Foxp3. Science 299: 1057-1061.

Horwitz DA. 2008. Regulatory T cells in systemic lupus erythematosus: Past, present and future. Arthritis Res Ther 10: 227.

Huang X, Stone DK, Yu F, Zeng Y, Gendelman HE. 2010. Functional proteomic analysis for regulatory $\mathrm{T}$ cell surveillance of the HIV-1 infected macrophage. J Proteome Res 9: 6759-6773.

Hunot S, Boissiere F, Faucheux B, Brugg B, Mouatt-Prigent A, Agid Y, Hirsch EC. 1996. Nitric oxide synthase and neuronal vulnerability in Parkinson's disease. Neuroscience 72: 355-363.

Jellinger KA. 2007. More frequent Lewy bodies but less frequent Alzheimer-type lesions in multiple system atrophy as compared to age-matched control brains. Acta Neuropathol 114: 299-303.

Johnson J, Pahuja A, Graham M, Hering B, Hancock WW, Bansal-Pakala P. 2008. Effects of histone deacetylase inhibitor SAHA on effector and FOXP $3^{+}$regulatory $\mathrm{T}$ cells in rhesus macaques. Transpl Proc 40: 459-461.

Kacimi R, Giffard RG, Yenari MA. 2011. Endotoxin-activated microglia injure brain derived endothelial cells via NF-кB, JAK-STAT and JNK stress kinase pathways. J Inflamm (Lond) 8: 7.

Kamer AR, Dasanayake AP, Craig RG, Glodzik-Sobanska L, Bry M, de Leon MJ. 2008. Alzheimer's disease and peripheral infections: The possible contribution from periodontal infections, model and hypothesis. J Alzheimers Dis 13: 437-449.

Karcher D, Federsppiel BS, Lowenthal FD, Frank F, Lowenthal A. 1986. Anti-neurofilament antibodies in blood of patients with neurological diseases. Acta Neuropathol 72: $82-85$.

Khattar M, Chen W, Stepkowski SM. 2009. Expanding and converting regulatory $\mathrm{T}$ cells: A horizon for immunotherapy. Arch Immunol Ther Exp 57: 199-204.

Kim J. 2005. Review of the innate immune response in acne vulgaris: Activation of Toll-like receptor 2 in acne triggers inflammatory cytokine responses. Dermatology 211: 193-198.

Kim WG, Mohney RP, Wilson B, Jeohn GH, Liu B, Hong JS 2000. Regional difference in susceptibility to lipopolysaccharide-induced neurotoxicity in the rat brain: Role of microglia. J Neurosci 20: 6309-6316.

Kim JM, Rasmussen JP, Rudensky AY. 2007. Regulatory $\mathrm{T}$ cells prevent catastrophic autoimmunity throughout the lifespan of mice. Nat Immunol 8: 191-197.

Kipnis J, Mizrahi T, Hauben E, Shaked I, Shevach E, Schwartz M. 2002. Neuroprotective autoimmunity: Naturally occurring $\mathrm{CD} 4{ }^{+} \mathrm{CD} 25^{+}$regulatory T cells suppress the ability to withstand injury to the central nervous system. Proc Natl Acad Sci 99: 15620-15625.

Kleinewietfeld M, Starke M, Di Mitri D, Borsellino G, Battistini L, Rötzschke O, Falk K. 2009. CD49d provides access to "untouched" human Foxp $3^{+} \mathrm{T}_{\text {reg }}$ free of contaminating effector cells. Blood 113: 827-836.

Koen V. 2010. Disturbed regulatory T cell homeostasis in multiple sclerosis. Trends Mol Med 16: 58.

Koprich JB, Johnston TH, Reyes MG, Sun X, Brotchie JM. 2010. Expression of human A53T $\alpha$-synuclein in the rat substantia nigra using a novel AAV1/2 vector produces a rapidly evolving pathology with protein aggregation, dystrophic neurite architecture and nigrostriatal degeneration with potential to model the pathology of Parkinson's disease. Mol Neurodegener 5: 43.

Kortekaas R, Leenders KL, van Oostrom JC, Vaalburg W, Bart J, Willemsen AT, Hendrikse NH. 2005. Blood-brain barrier dysfunction in parkinsonian midbrain in vivo. Ann Neurol 57: 176-179.

Kosloski LM, Ha DM, Hutter JA, Stone DK, Pichler MR, Reynolds AD, Gendelman HE, Mosley RL. 2010. 
Adaptive immune regulation of glial homeostasis as an immunization strategy for neurodegenerative diseases. J Neurochem 114: 1261-1276.

Kruger R, Kuhn W, Muller T, Woitalla D, Graeber M, Kosel S, Przuntek H, Epplen JT, Schols L, Riess O. 1998. Ala30Pro mutation in the gene encoding $\alpha$-synuclein in Parkinson's disease. Nat Genet 18: 106-108.

Kunas RC, McRae A, Kesselring J, Villiger PM. 1995. Antidopaminergic antibodies in a patient with a complex autoimmune disorder and rapidly progressing Parkinson's disease. J Allergy Clin Immunol 96: 688-690.

Lampe JB, Gossrau G, Herting B, Kempe A, Sommer U, Fussel M, Weber M, Koch R, Reichmann H. 2003. HLA typing and Parkinson's disease. Eur Neurol 50: 64-68.

Lawson LJ, Perry VH, Dri P, Gordon S. 1990. Heterogeneity in the distribution and morphology of microglia in the normal adult mouse brain. Neuroscience 39: 151-170.

Lee SJ. 2008. Origins and effects of extracellular $\alpha$-synuclein: Implications in Parkinson's disease. J Molec Neurosci 34: $17-22$.

Lee JK, Tran T, Tansey MG. 2009a. Neuroinflammation in Parkinson's disease. J Neuroimmune Pharmacol 4: 419_ 429.

Lee YK, Mukasa R, Hatton RD, Weaver CT. 2009b. Developmental plasticity of Th17 and $\mathrm{T}_{\text {reg }}$ cells. Curr Opin Immunol 21: $274-280$

Li J, Uversky VN, Fink AL. 2001. Effect of familial Parkinson's disease point mutations A30P and A53T on the structural properties, aggregation, and fibrillation of human $\alpha$-synuclein. Biochemistry 40: 11604-11613.

Liu J, Gong N, Huang X, Reynolds AD, Mosley RL, Gendelman HE. 2009. Neuromodulatory activities of $\mathrm{CD} 4^{+}$ $\mathrm{CD}^{2} 5^{+}$regulatory T cells in a murine model of HIV-1-associated neurodegeneration. J Immunol 182: 3855-3865.

Lucas JL, Mirshahpanah P, Haas-Stapleton E, Asadullah K, Zollner TM, Numerof RP. 2009. Induction of Foxp3 ${ }^{+}$ regulatory $\mathrm{T}$ cells with histone deacetylase inhibitors. Cell Immunol 257: 97-104.

Lv M, Liu Y, Zhang J, Sun L, Liu Z, Zhang S, Wang B, Su D, Su Z. 2011. Roles of inflammation response in microglia cell through Toll-like receptors $2 /$ interleukin-23/interleukin-17 pathway in cerebral ischemia/reperfusion injury. Neuroscience 176: 162-172.

Maloy KJ, Salaun L, Cahill R, Dougan G, Saunders NJ, Powrie F. 2003. $\mathrm{CD}^{+} \mathrm{CD} 25^{+} \mathrm{T}(\mathrm{R})$ cells suppress innate immune pathology through cytokine-dependent mechanisms. J Exp Med 197: 111-119.

McColl BW, Allan SM, Rothwell NJ. 2009. Systemic infection, inflammation and acute ischemic stroke. Neuroscience 158: 1049-1061.

McGeer EG, McGeer PL. 2003. Inflammatory processes in Alzheimer's disease. Prog Neuropsychopharmacol Biol Psychiatry 27: 741-749.

McGeer PL, McGeer EG. 2008. Glial reactions in Parkinson's disease. Mov Disord 23: 474-483.

McGeer EG, Singh EA, McGeer PL. 1988a. Peripheral-type benzodiazepine binding in Alzheimer disease. Alzheimer Dis Assoc Disord 2: 331-336.

McGeer PL, Itagaki S, Boyes BE, McGeer EG. 1988b. Reactive microglia are positive for HLA-DR in the substantia nigra of Parkinson's and Alzheimer's disease brains. Neurology 38: 1285-1291.

McRae-Degueurce A, Rosengren L, Haglid K, Booj S, Gottfries CG, Granerus AC, Dahlstrom A. 1988. Immunocytochemical investigations on the presence of neuronspecific antibodies in the CSF of Parkinson's disease cases. Neurochem Res 13: 679-684.

Medawar PB. 1948. Immunity to homologous grafted skin; the fate of skin homografts transplanted to the brain, to subcutaneous tissue, and to the anterior chamber of the eye. Br J Exp Pathol 29: 58-69.

Miklossy J, Doudet DD, Schwab C, Yu S, McGeer EG, McGeer PL. 2006. Role of ICAM-1 in persisting inflammation in Parkinson disease and MPTP monkeys. Exp Neurol 197: 275-283.

Moore S, Thanos S. 1996. The concept of microglia in relation to central nervous system disease and regeneration. Progr Neurobiol 48: 441-460.

Mu L, Sun B, Kong Q, Wang J, Wang G, Zhang S, Wang D, Liu Y, Liu Y, An H, et al. 2009. Disequilibrium of T helper type 1, 2 and 17 cells and regulatory T cells during the development of experimental autoimmune myasthenia gravis. Immunology 128: e826-e836.

Nalls MA, Plagnol V, Hernandez DG, Sharma M, Sheerin UM, Saad M, Simon-Sanchez J, Schulte C, Lesage S, Sveinbjornsdottir S, et al. 2011. Imputation of sequence variants for identification of genetic risks for Parkinson's disease: A meta-analysis of genome-wide association studies. Lancet 377: 641-649.

Narhi L, Wood SJ, Steavenson S, Jiang Y, Wu GM, Anafi D, Kaufman SA, Martin F, Sitney K, Denis P, et al. 1999. Both familial Parkinson's disease mutations accelerate $\alpha$-synuclein aggregation. J Biol Chem 274: 9843-9846.

Olson JK, Miller SD. 2004. Microglia initiate central nervous system innate and adaptive immune responses through multiple TLRs. J Immunol 173: 3916-3924.

Orr CF, Rowe DB, Mizuno Y, Mori H, Halliday GM. 2005. A possible role for humoral immunity in the pathogenesis of Parkinson's disease. Brain 128: 2665-2674.

Papachroni KK, Ninkina N, Papapanagiotou A, Hadjigeorgiou GM, Xiromerisiou G, Papadimitriou A, Kalofoutis A, Buchman VL. 2007. Autoantibodies to $\alpha$-synuclein in inherited Parkinson's disease. J Neurochem 101: 749756.

Parihar MS, Parihar A, Fujita M, Hashimoto M, Ghafourifar P. 2009. $\alpha$-Synuclein overexpression and aggregation exacerbates impairment of mitochondrial functions by augmenting oxidative stress in human neuroblastoma cells. Int J Biochem Cell Biol 41: 2015-2024.

Perry VH. 2010. Contribution of systemic inflammation to chronic neurodegeneration. Acta Neuropathol 120: 277 286.

* Perry VH. 2011. Innate inflammation in Parkinson's disease. Cold Spring Harb Perspect Med doi: 10.1101/cshperspect.a009373.

Petito CK, Cash KS. 1992. Blood-brain barrier abnormalities in the acquired immunodeficiency syndrome: Immunohistochemical localization of serum proteins in postmortem brain. Ann Neurol 32: 658-666.

Petito CK, Adkins B, McCarthy M, Roberts B, Khamis I. 2003. $\mathrm{CD} 4^{+}$and $\mathrm{CD} 8^{+}$cells accumulate in the brains of 
R.L. Mosley et al.

acquired immunodeficiency syndrome patients with human immunodeficiency virus encephalitis. J Neurovirol 9: 36-44.

Poletaev AB, Morozov SG, Gnedenko BB, Zlunikin VM, Korzhenevskey DA. 2000. Serum anti-S100b, anti-GFAP and anti-NGF autoantibodies of IgG class in healthy persons and patients with mental and neurological disorders. Autoimmunity 32: 33-38.

Polymeropoulos MH, Higgins JJ, Golbe LI, Johnson WG, Ide SE, Di Iorio G, Sanges G, Stenroos ES, Pho LT, Schaffer AA, et al. 1996. Mapping of a gene for Parkinson's disease to chromosome 4q21-q23. Science 274: 1197-1199.

Polymeropoulos MH, Lavedan C, Leroy E, Ide SE, Dehejia A, Dutra A, Pike B, Root H, Rubenstein J, Boyer R, et al. 1997. Mutation in the $\alpha$-synuclein gene identified in families with Parkinson's disease. Science 276: 2045-2047.

Ponomarev ED, Dittel BN. 2005. $\gamma \delta$ T cells regulate the extent and duration of inflammation in the central nervous system by a Fas ligand-dependent mechanism. J Immunol 174: $4678-4687$.

Puschmann A, Verbeeck C, Heckman MG, Soto-Ortolaza AI, Lynch T, Jasinska-Myga B, Opala G, Krygowska-Wajs A, Barcikowska M, Uitti RJ, et al. 2011. Human leukocyte antigen variation and Parkinson's disease. Parkinsonism Relat Disord 17: 376-378.

Putnam AL, Brusko TM, Lee MR, Liu W, Szot GL, Ghosh T, Atkinson MA, Bluestone JA. 2009. Expansion of human regulatory T-cells from patients with type 1 diabetes. Diabetes 58: 652-662.

Qiu WQ, Ye Z, Kholodenko D, Seubert P, Selkoe DJ. 1997. Degradation of amyloid $\beta$-protein by a metalloprotease secreted by microglia and other neural and non-neural cells. J Biol Chem 272: 6641-6646.

Reale M, Iarlori C, Thomas A, Gambi D, Perfetti B, Di Nicola M, Onofrj M. 2009. Peripheral cytokines profile in Parkinson's disease. Brain Behav Immun 23: 55-63.

Rentzos M, Nikolaou C, Andreadou E, Paraskevas GP, Rombos A, Zoga M, Tsoutsou A, Boufidou F, Kapaki E, Vassilopoulos D. 2007. Circulating interleukin-15 and RANTES chemokine in Parkinson's disease. Acta Neurol Scand 116: 374-379.

Rentzos M, Nikolaou C, Andreadou E, Paraskevas GP, Rombos A, Zoga M, Tsoutsou A, Boufidou F, Kapaki E, Vassilopoulos D. 2009. Circulating interleukin-10 and interleukin-12 in Parkinson's disease. Acta Neurol Scand 119: $332-337$.

Reynolds AD, Banerjee R, Liu J, Gendelman HE, Mosley RL. 2007. Neuroprotective activities of $\mathrm{CD} 4^{+} \mathrm{CD} 25^{+}$regulatory T cells in an animal model of Parkinson's disease. J Leuk Biol 82: 1083-1094.

Reynolds AD, Glanzer JG, Kadiu I, Ricardo-Dukelow M, Chaudhuri A, Ciborowski P, Cerny R, Gelman B, Thomas MP, Mosley RL, et al. 2008a. Nitrated $\alpha$-synuclein-activated microglial profiling for Parkinson's disease. J Neurochem 104: 1504-1525.

Reynolds AD, Kadiu I, Garg SK, Glanzer JG, Nordgren T, Ciborowski P, Banerjee R, Gendelman HE. 2008b. Nitrated $\alpha$-synuclein and microglial neuroregulatory activities. J Neuroimmune Pharmacol 3: 59-74.

Reynolds AD, Stone DK, Mosley RL, Gendelman HE. 2009. Proteomic studies of nitrated $\alpha$-synuclein microglia regulation by $\mathrm{CD} 4{ }^{+} \mathrm{CD} 25^{+}$T Cells. J Proteome Res 8: 3497-3511.

Reynolds AD, Stone DK, Hutter JA, Benner EJ, Mosley RL, Gendelman HE. 2010. Regulatory T cells attenuate th17 cell-mediated nigrostriatal dopaminergic neurodegeneration in a model of Parkinson's disease. J Immunol 184: 2261-2271.

Rock RB, Gekker G, Hu S, Sheng WS, Cheeran M, Lokensgard JR, Peterson PK. 2004. Role of microglia in central nervous system infections. Clin Microbiol Rev 17: $942-$ 964.

Rogers J, Luber-Narod J, Styren SD, Civin WH. 1988. Expression of immune system-associated antigens by cells of the human central nervous system: Relationship to the pathology of Alzheimer's disease. Neurobiol Aging 9: 339-349.

Royal W III, Mia Y, Li H, Naunton K. 2009. Peripheral blood regulatory $\mathrm{T}$ cell measurements correlate with serum vitamin D levels in patients with multiple sclerosis. J Neuroimmunol 213: 135-141.

Saiki M, Baker A, Williams-Gray CH, Foltynie T, Goodman RS, Taylor CJ, Compston DA, Barker RA, Sawcer SJ, Goris A. 2010. Association of the human leucocyte antigen region with susceptibility to Parkinson's disease. J Neurol Neurosurg Psychiatry 81: 890-891.

Sakaguchi S. 2004. Naturally arising $\mathrm{CD} 4^{+}$regulatory T cells for immunologic self-tolerance and negative control of immune responses. Ann Rev Immunol 22: 531-562.

Sakaguchi S. 2011. Regulatory T cells: History and perspective. Methods Mol Biol 707: 3-17.

Sakaguchi S, Sakaguchi N, Asano M, Itoh M, Toda M. 1995 Immunologic self-tolerance maintained by activated $\mathrm{T}$ cells expressing IL-2 receptor $\alpha$-chains (CD25). Breakdown of a single mechanism of self-tolerance causes various autoimmune diseases. J Immunol 155: 1151-1164.

Saouaf SJ, Li B, Zhang G, Shen Y, Furuuchi N, Hancock WW, Greene MI. 2009. Deacetylase inhibition increases regulatory $\mathrm{T}$ cell function and decreases incidence and severity of collagen-induced arthritis. Exp Mol Pathol 87: 99-104.

Sawada M, Kondo N, Suzumura A, Marunouchi T. 1989. Production of tumor necrosis factor- $\alpha$ by microglia and astrocytes in culture. Brain Res 491: 394-397.

Shavali S, Combs CK, Ebadi M. 2006. Reactive macrophages increase oxidative stress and $\alpha$-synuclein nitration during death of dopaminergic neuronal cells in co-culture: Relevance to Parkinson's disease. Neurochem Res 31: 85-94.

Shimura H, Schlossmacher MG, Hattori N, Frosch MP, Trockenbacher A, Schneider R, Mizuno Y, Kosik KS, Selkoe DJ. 2001. Ubiquitination of a new form of $\alpha$-synuclein by parkin from human brain: Implications for Parkinson's disease. Science 293: 263-269.

Simon-Sanchez J, van Hilten JJ, van de Warrenburg B, Post B, Berendse HW, Arepalli S, Hernandez DG, de Bie RM, Velseboer D, Scheffer H, et al. 2011. Genome-wide association study confirms extant PD risk loci among the Dutch. Eur J Hum Genet 19: 655-661.

Singleton AB, Farrer M, Johnson J, Singleton A, Hague S, Kachergus J, Hulihan M, Peuralinna T, Dutra A, Nussbaum R, et al. 2003. $\alpha$-Synuclein locus triplication causes Parkinson's disease. Science 302: 841. 
Sly PD, Holt PG. 2011. Role of innate immunity in the development of allergy and asthma. Curr Opin Allergy Clin Immunol 11: 127-131.

Spillantini MG, Schmidt ML, Lee VM, Trojanowski JQ, Jakes R, Goedert M. 1997. $\alpha$-Synuclein in Lewy bodies. Nature 388: 839-840.

Spillantini MG, Crowther RA, Jakes R, Hasegawa M, Goedert M. 1998. $\alpha$-Synuclein in filamentous inclusions of Lewy bodies from Parkinson's disease and dementia with Lewy bodies. Proc Natl Acad Sci 95: 6469-6473.

Stearns-Kurosawa DJ, Osuchowski MF, Valentine C, Kurosawa S, Remick DG. 2011. The pathogenesis of sepsis. Annu Rev Pathol 6: 19-48.

Stoll G, Bendszus M. 2009. Imaging of inflammation in the peripheral and central nervous system by magnetic resonance imaging. Neuroscience 158: 1151-1160.

Stolp HB, Dziegielewska KM. 2009. Review: Role of developmental inflammation and blood-brain barrier dysfunction in neurodevelopmental and neurodegenerative diseases. Neuropathol Appl Neurobiol 35: 132-146.

Stone DK, Reynolds AD, Mosley RL, Gendelman HE. 2009. Innate and adaptive immunity for the pathobiology of Parkinson's disease. Antioxid Redox Signal 11: 2151-2166.

Tao R, de Zoeten EF, Ozkaynak E, Wang L, Li B, Greene MI, Wells AD, Hancock WW. 2007. Histone deacetylase inhibitors and transplantation. Curr Opin Immunol 19: 589-595.

Teeling JL, Perry VH. 2009. Systemic infection and inflammation in acute CNS injury and chronic neurodegeneration: Underlying mechanisms. Neuroscience 158: 1062 1073.

Teismann P, Tieu K, Choi DK, Wu DC, Naini A, Hunot S, Vila M, Jackson-Lewis V, Przedborski S. 2003. Cyclooxygenase-2 is instrumental in Parkinson's disease neurodegeneration. Proc Natl Acad Sci 100: 5473-5478.

Terryberry JW, Thor G, Peter JB. 1998. Autoantibodies in neurodegenerative diseases: Antigen-specific frequencies and intrathecal analysis. Neurobiol Aging 19: 205-216.

Togo T, Akiyama H, Iseki E, Kondo H, Ikeda K, Kato M, Oda T, Tsuchiya K, Kosaka K. 2002. Occurrence of T cells in the brain of Alzheimer's disease and other neurological diseases. J Neuroimmunol 124: 83-92.

Uversky VN. 2007. Neuropathology, biochemistry, and biophysics of $\alpha$-synuclein aggregation. J Neurochem 103: 17-37.

Uversky VN, Yamin G, Munishkina LA, Karymov MA, Millett IS, Doniach S, Lyubchenko YL, Fink AL. 2005. Effects of nitration on the structure and aggregation of $\alpha$-synuclein. Brain Res Molec Brain Res 134: 84-102.

Vandenbark AA, Huan J, Agotsch M, La Tocha D, Goelz S, Offner H, Lanker S, Bourdette D. 2009. Interferon- $\beta$-1a treatment increases CD56bright natural killer cells and $\mathrm{CD} 4{ }^{+} \mathrm{CD} 25^{+}$Foxp 3 expression in subjects with multiple sclerosis. J Neuroimmunol 215: 125-128.

Veerhuis R, Nielsen HM, Tenner AJ. 2011. Complement in the brain. Mol Immunol 48: 1592-1603.

Venigalla RK, Tretter T, Krienke S, Max R, Eckstein V, Blank N, Fiehn C, Ho AD, Lorenz HM. 2008. Reduced CD4 ${ }^{+}$, $\mathrm{CD} 25^{-} \mathrm{T}$ cell sensitivity to the suppressive function of $\mathrm{CD} 4^{+}, \mathrm{CD} 25$ high, $\mathrm{CD} 127^{-} /$low regulatory $\mathrm{T}$ cells in pa-
Inflammation and Immunity in Parkinson's Disease

tients with active systemic lupus erythematosus. Arthr Rheum 58: 2120-2130.

Venken K, Hellings N, Broekmans T, Hensen K, Rummens JL, Stinissen P. 2008. Natural naive $\mathrm{CD} 4^{+} \mathrm{CD} 25^{+}$ CD127low regulatory $\mathrm{T}$ cell $\left(\mathrm{T}_{\text {reg }}\right)$ development and function are disturbed in multiple sclerosis patients: Recovery of memory $\mathrm{T}_{\text {reg }}$ homeostasis during disease progression. J Immunol 180: 6411-6420.

Wahl SM, Swisher J, McCartney-Francis N, Chen W. 2004. TGF- $\beta$ : The perpetrator of immune suppression by regulatory T cells and suicidal T cells. J Leuk Biol 76: 15-24.

Weiner HL. 2008. A shift from adaptive to innate immunity: A potential mechanism of disease progression in multiple sclerosis. J Neurol 255 (Suppl 1): 3-11.

Wong D, Prameya R, Dorovini-Zis K. 1999. In vitro adhesion and migration of $\mathrm{T}$ lymphocytes across monolayers of human brain microvessel endothelial cells: Regulation by ICAM-1, VCAM-1, E-selectin and PECAM-1. J Neuropathol Exp Neurol 58: 138-152.

Xue K, Zhou Y, Xiong S, Xiong W, Tang T. 2007. Analysis of $\mathrm{CD} 4{ }^{+} \mathrm{CD} 25^{+}$regulatory $\mathrm{T}$ cells and Foxp 3 mRNA in the peripheral blood of patients with asthma. J Huazhong Univ Sci Technolog Med Sci 27: 31-33.

Yanamandra K, Gruden MA, Casaite V, Meskys R, Forsgren L, Morozova-Roche LA. 2011. $\alpha$-Synuclein reactive antibodies as diagnostic biomarkers in blood sera of Parkinson's disease patients. PLoS One 6: e18513.

Yeager MP, DeLeo JA, Hoopes PJ, Hartov A, Hildebrandt L, Hickey WF. 2000. Trauma and inflammation modulate lymphocyte localization in vivo: Quantitation of tissue entry and retention using indium-111-labeled lymphocytes. Crit Care Med 28: 1477-1482.

Zappia M, Crescibene L, Bosco D, Arabia G, Nicoletti G, Bagala A, Bastone L, Napoli ID, Caracciolo M, Bonavita S, et al. 2002. Anti-GM1 ganglioside antibodies in Parkinson's disease. Acta Neurol Scand 106: 54-57.

Zarranz JJ, Alegre J, Gomez-Esteban JC, Lezcano E, Ros R, Ampuero I, Vidal L, Hoenicka J, Rodriguez O, Atares B, et al. 2004. The new mutation, E46K, of $\alpha$-synuclein causes Parkinson and Lewy body dementia. Ann Neurol 55: $164-173$.

Zhang SC, Fedoroff S. 1996. Neuron-microglia interactions in vitro. Acta Neuropathol 91: 385-395.

Zhang W, Wang T, Pei Z, Miller DS, Wu X, Block ML, Wilson B, Zhou Y, Hong JS, Zhang J. 2005. Aggregated $\alpha$-synuclein activates microglia: A process leading to disease progression in Parkinson's disease. FASEB J 19: 533-542.

Zheng SG, Wang J, Wang P, Gray JD, Horwitz DA. 2007. IL-2 is essential for TGF- $\alpha$ to convert naive $\mathrm{CD} 4{ }^{+} \mathrm{CD} 25^{-}$cells to $\mathrm{CD} 25^{+}$Foxp $^{+}$regulatory $\mathrm{T}$ cells and for expansion of these cells. J Immunol 178: 2018-2027.

Zheng SG, Wang J, Horwitz DA. 2008. Cutting edge: Foxp $3{ }^{+} \mathrm{CD} 4{ }^{+} \mathrm{CD} 25^{+}$regulatory $\mathrm{T}$ cells induced by IL-2 and TGF-ßare resistant to Th17 conversion by IL-6. J Immunol 180: 7112-7116.

Zurolo E, Iyer A, Maroso M, Carbonell C, Anink JJ, Ravizza T, Fluiter K, Spliet WG, van Rijen PC, Vezzani A, et al. 2011. Activation of toll-like receptor, RAGE and HMGB1 signalling in malformations of cortical development. Brain 134: 1015-1032. 


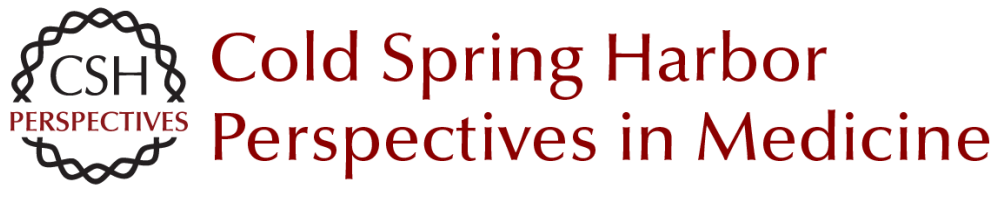

\section{Inflammation and Adaptive Immunity in Parkinson's Disease}

R. Lee Mosley, Jessica A. Hutter-Saunders, David K. Stone and Howard E. Gendelman

Cold Spring Harb Perspect Med 2012; doi: 10.1101/cshperspect.a009381 originally published online November 15, 2011

\section{Subject Collection Parkinson's Disease}

Functional Neuroanatomy of the Basal Ganglia José L. Lanciego, Natasha Luquin and José A. Obeso

Animal Models of Parkinson's Disease: Vertebrate Genetics Yunjong Lee, Valina L. Dawson and Ted M. Dawson

Innate Inflammation in Parkinson's Disease V. Hugh Perry

Parkinson's Disease and Parkinsonism:

Neuropathology Dennis W. Dickson

Physiological Phenotype and Vulnerability in Parkinson's Disease

D. James Surmeier, Jaime N. Guzman, Javier Sanchez, et al.

Clinical Approach to Parkinson's Disease:

Features, Diagnosis, and Principles of Management João Massano and Kailash P. Bhatia

The Role of Autophagy in Parkinson's Disease Melinda A. Lynch-Day, Kai Mao, Ke Wang, et al.

Disruption of Protein Quality Control in Parkinson's Disease Casey Cook, Caroline Stetler and Leonard Petrucelli
Drosophila as a Model to Study Mitochondrial Dysfunction in Parkinson's Disease Ming Guo

Parkinsonism Due to Mutations in PINK1, Parkin, and DJ-1 and Oxidative Stress and Mitochondrial Pathways Mark R. Cookson

Programmed Cell Death in Parkinson's Disease Katerina Venderova and David S. Park

Genomics and Bioinformatics of Parkinson's Disease Sonja W. Scholz, Tim Mhyre, Habtom Ressom, et al.

Motor Control Abnormalities in Parkinson's

Disease Pietro Mazzoni, Britne Shabbott and Juan Camilo Cortés

Parkinson's Disease: Gene Therapies Philippe G. Coune, Bernard L. Schneider and Patrick Aebischer

Functional Neuroimaging in Parkinson's Disease Martin Niethammer, Andrew Feigin and David Eidelberg

Leucine-Rich Repeat Kinase 2 for Beginners: Six Key Questions Lauren R. Kett and William T. Dauer

For additional articles in this collection, see http://perspectivesinmedicine.cshlp.org/cgi/collection/ 